\title{
Comparative study of the areas of osteochondral defects produced in the femoral condyles of rabbits treated with gel of sugarcane biopolymer ${ }^{1}$
}

\author{
Estudo comparativo das áreas de defeitos osteocondrais produzidas nos côndilos femorais de \\ coelhos tratados com gel de biopolímero de cana
}

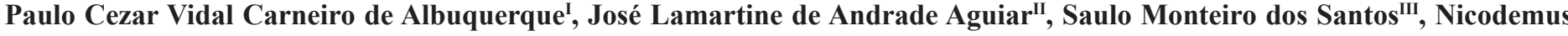 \\ Pontes Filho ${ }^{\mathrm{IV}}$, Roberto José Vieira de Mello ${ }^{\mathrm{IV}}$, Mariana Lúcia Correia Ramos Costav, Clarissa Miranda Carneiro de \\ Albuquerque $^{\mathrm{VI}}$, Tarciana Mendonça de S. Almeida ${ }^{\mathrm{VI}}$, Alessandro Henrique da Silva Santos ${ }^{\mathrm{VII}}$, Joacil Carlos da Silva ${ }^{\mathrm{VIII}}$ \\ IFellow Master degree, Associate Professor, Department of Surgery, UFPE, Recife-PE, Brazil. Main author. Conception, design, intellectual and \\ scientific content of the study. \\ IIAssociate Professor, Department of Sugery, UFPE, Recife-PE, Brazil. Supervised all phases of the study and manuscript writing. \\ IIIAssociate Professor, Department of Sugery, UFPE, Recife-PE, Brazil. Responsible for conception of the study and critical revision.

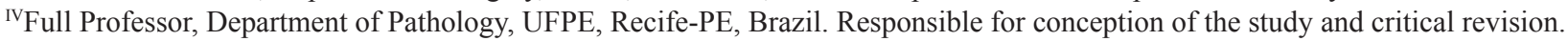 \\ ${ }^{\mathrm{v} F e l l o w}$ Master degree, Department of Pathology, UFPE, Recife-PE, Brazil. Acquisition and interpretation of data. \\ ${ }^{\mathrm{VI}}$ Graduate student, School of Medicine, UFPE, Recife-PE, Brazil. Acquisition and interpretation of data.

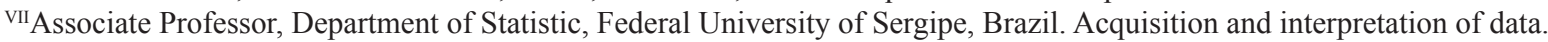 \\ ${ }^{\mathrm{VIII}}$ Fellow Master degree, Departament of Neuropschiatry, UFPE, Recife-PE, Brazil. Acquisition and interpretation of data.
}

\begin{abstract}
PURPOSE: To measure the healed areas of osteochondral defects produced in femoral condyles of rabbits filled with biopolymer sugar cane gel and to compare these with those of the control group at 90,120 and 180 days.

METHODS: A study was made of $16 \mathrm{New}$ Zealand rabbits, 6 and 7 months old, weighing between 2 and $2.5 \mathrm{~kg}$. Defects of $3.2 \mathrm{x} 4 \mathrm{~mm}$ were made, with trephine, in the femoral condyles of the right and left knees. As to the study group defects of the medial and lateral condyles of the right knee were used which were filled with Biopolymer Sugar Cane Gel; as to the Control Group defects of the medial and lateral condyles of the left $t$ knees were used which were left open for natural healing. The defects were analyzed at 90,120 and 180 days after surgery. After euthanasia, the knees were removed and fixed in Bouin's solution for later digital photographic documentation with a digital camera. The areas healed were measured in both the study and control groups using the images obtained from an Image- $\mathrm{J}^{\mathbb{R}}$ program. Statistical analysis was conducted using the non-parametric Mann-Whitney test.

RESULTS: There were no significant differences between the means of the healed areas in the study and control groups at 90,120 and 180 days after surgery.

CONCLUSION: The dimension of the healed areas of the defects treated with the biopolymer sugar-cane gel in the study group was similar to those of the control group, which healed naturally.
\end{abstract}

Keywords: Cartilage. Anatomy. Histology. Saccharum. Biopolymers. Rabbits.

\section{RESUMO}

OBJETIVO: Mensurar as áreas cicatrizadas dos defeitos osteocondrais produzidos em côndilos femorais de coelhos preenchidos com gel de biopolímero da cana-de-açúcar e comparar com o grupo controle nos períodos de 90, 120 e 180 dias.

MÉTODOS: Foram estudados, 16 coelhos da raça Nova Zelândia com seis a sete meses de idade, entre 2,0 e 2,5 kg de peso. Foram feitos, com trefina, defeitos de 3,2 x 4 mm nos côndilos femorais dos joelhos direito e esquerdo. Como grupo de estudo foram utilizados os defeitos dos côndilos medial e lateral dos joelhos direito que foram preenchidos com gel de biopolímero da cana-de-açucar. Como grupo controle foram utilizados os defeitos dos côndilos medial e lateral dos joelhos esquerdos que foram deixados abertos para cicatrização natural. Os defeitos foram analisados nos períodos de 90, 120 e 180 dias após a cirurgia. Após a eutanásia, os joelhos foram retirados e fixados em solução de Bouin para posterior documentação fotográfica com maquina digital Nikon Coopix ${ }^{\circledR} 5400$. As áreas cicatrizadas foram mensuradas nos grupos estudo e controle, através das imagens obtidas com o programa Image- $\mathrm{J}^{\circledR}$. A análise estatística foi feita aplicando-se o teste não paramétrico Mann-Whitney.

RESULTADOS: Não houve diferenças significantes entre as médias das áreas cicatrizadas nos grupos estudo e controle nos períodos de 90, 120 e 180 dias após a cirurgia.

CONCLUSÃO: A dimensão das áreas cicatrizadas dos defeitos tratados com o gel do biopolímero da cana-de-açúcar, grupo de estudo foi semelhante as do grupo controle, cicatrizadas naturalmente.

Descritores: Cartilagem. Anatomia. Histologia. Saccharum. Biopolímeros. Coelhos. 


\section{Introduction}

The use of different polymers in orthopedics to fill osteochondral defects has a recent history. This new area of biomaterial research aims to develop implants, endowed with properties biocompatible with bone tissue ${ }^{1-3}$.

The repair of osteochondral defects is complex and not yet fully elucidated ${ }^{4-9}$. Whatever the cause, the healing of these defects follows a sequence of events that can be divided into three phases, in accordance with the morphological changes: the inflammatory phase, a repair phase and a remodelling one ${ }^{8-16}$. In the inflammatory phase, hematomas are formed and reorganized, platelet growth factors are released and tissue formed which is rich in progenitory cells derived from within the bone tissue itself and peripheral blood. These cells, in the repair phase, will form the primary bone tissue, by a process similar to endochondral or intramembranous ossification ${ }^{6,7}$. Subsequently, this tissue undergoes remodeling aided by osteoclasts until mature or lamellar bone is formed. This phase can last months or years until the newly formed bone, by mechanical forces, acquires the structural and physiological characteristics the bone had prior to the $\operatorname{defect}^{6-8}$.

Osteochondral healing led by biopolymers offers protection against the invasion of competing non-osteogenic tissues. It is for this reason that the defects are filled in with organic or inorganic matrices, which are slowly re-absorbed and replaced by newly formed tissue ${ }^{6-9}$.

The aim of this study was to measure the areas of the healed defects, produced in the femoral condyle of rabbits, after filling them with biopolymer sugar-cane gel (BPSCG), at 90, 120 and 180 days, compared with the group control which underwent natural healing.

\section{Methods}

The procedures were conducted under veterinary supervision and approved by the Ethics Committee on Animal Experimentation of the Center for Biological Sciences, Federal University of Pernambuco (UFPE-EAEC). The use of laboratory animals followed the ethical code for animal experimentation of the Council for International Organization of Medical Sciences and the Brazilian College on Animal Experimentation.

16 rabbits were studied. They were white, young adults of the New Zealand breed, which were between 6 and 7 months old, weighing between 2 and $2.5 \mathrm{~kg}$, with no changes in their locomotor apparatus, and came from the breeding centers of the Association of Rabbit-breeders of Pernambuco and kept in the animal colony of the Nucleus of Experimental Surgery of the Federal University of Pernambuco. The animals were confined in metal cages, were able to roam freely and were fed with standard pellets and water ad libitum.

\section{Surgical technique}

The rabbits underwent general anaesthesia with 5\% ketamine hydrochloride at a dosage of $50 \mathrm{mg} / \mathrm{kg}$ of weight, associated with $10 \%$ chloral hydrate at a dosage of $0.5 \mathrm{ml} / \mathrm{kg}$ of weight and complemented with local anaesthesia, $5 \mathrm{ml}$ of $2 \%$ xylocaine diluted in $9 \mathrm{ml}$ of distilled water.

After shaving the surgical area, antisepsis was performed with iodine solution and affixing a fenestrated surgical field. A medial incision was made, followed by arthrotomy and lateral dislocation of the patella for a better view. With the knee flexed, each femoral condyle was exposed and with the aid of metallic trephine, osteochondral defects of $3.2 \mathrm{~mm}$ in diameter and 4.0 $\mathrm{mm}$ deep were produced in the femoral condyles of each knee. The animals were divided into two groups: Study Group, right knee, the medial and lateral condyles were filled with BPSCG; and the Control Group, left knee, the medial and lateral condyles, the defects being left unfilled. Follow-up on the animals was by clinical observation, without restricting mobilization of the knees operated on. No state of infection was diagnosed.

Then, resection of the anatomical specimens, which were immersed in Bouin's solution, was performed, with the aim of taking photographic documentation.

A computer graphics program - Image $\mathrm{J}^{\circledR}$, version 1.3 for Windows, program was used to measure the healed area, and the images were photographed with a Nikon Coolpix ${ }^{\circledR} 5400$ digital camera, attached to a Nikon ${ }^{\circledR}$ SM2800 stereomicroscope.

For the calibration data of computer graphics, an Image-J version 1.3 for Windows ${ }^{\circledR}$ program was used, and the intercondylar distance measured in centimeters was adopted as a parameter. The size of the healing area was measured and compared with the control group. We considered the defect was completely repaired when the macroscopic characteristics were uniform.

Measurement of the area by the Image $\mathrm{J}$ program in photographic documentation of the femoral condyles.

Statistical analysis was performed using the nonparametric Mann-Whitney test. A significance level of $\mathrm{p}<0.05 \%$ was accepted to reject the null hypothesis. 


\section{Results}

The measurement in centimeters, compared to the scarred areas of femoral condyles in both the study and control group showed no significant differences (Figure 1 and Tables 1, 2, 3).
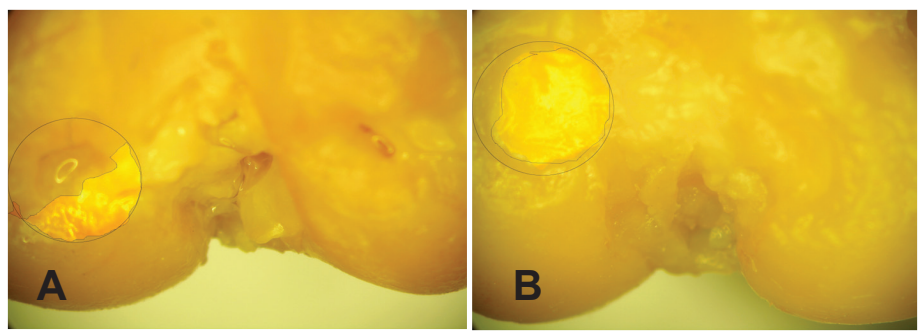

FIGURE 1 - Characterization of digital measurement the healing of defects. Observe the healing of the right condyle treated with biopolymer gel (A) and the left condyle naturally healed (B).

TABLE 1 - Measurement of areas in $\mathrm{cm}^{2}$ of healed osteochondral defects in the medial and lateral condyles, the period of 90 days in 06 rabbits of both groups.

\begin{tabular}{|c|c|c|c|c|c|}
\hline \multirow[b]{3}{*}{ Period } & \multirow[b]{3}{*}{ Animal } & \multicolumn{4}{|c|}{ Healed areas $\left(\mathrm{cm}^{2}\right)$} \\
\hline & & \multicolumn{2}{|c|}{ Study group } & \multicolumn{2}{|c|}{ Control group } \\
\hline & & Medial & Lateral & Medial & Lateral \\
\hline \multirow{6}{*}{90} & 6 & 0.0820 & 0.0290 & 0.0800 & 0.0480 \\
\hline & 7 & 0.0560 & 0.0600 & 0.0630 & 0.0630 \\
\hline & 8 & 0.0560 & 0.0410 & 0.0590 & 0.0390 \\
\hline & 13 & 0.0710 & 0.0790 & 0.0500 & 0.0800 \\
\hline & 19 & 0.0140 & 0.0580 & 0.0460 & 0.0160 \\
\hline & 22 & 0.0670 & 0.0670 & 0.0560 & 0.0820 \\
\hline Average & & 0.05767 & 0.0557 & 0.05900 & 0.0547 \\
\hline $\begin{array}{c}\text { Standard } \\
\text { Deviation } \\
\end{array}$ & & 0.0235 & 0.0180 & 0.0120 & 0.0255 \\
\hline $\mathrm{p}$ - medial value & & \multicolumn{4}{|c|}{0.699} \\
\hline $\mathrm{p}$ - lateral value & & \multicolumn{4}{|c|}{0.937} \\
\hline
\end{tabular}

Mann-Whitney
TABLE 2 - Measurement of areas in $\mathrm{cm}^{2}$ of healed osteochondral defects in the medial and lateral condyles, from 120 days in 05 rabbits of both groups.

\begin{tabular}{|c|c|c|c|c|c|}
\hline \multirow[b]{3}{*}{ Period } & \multirow[b]{3}{*}{ Animal } & \multicolumn{4}{|c|}{ Healed areas $\left(\mathrm{cm}^{2}\right)$} \\
\hline & & \multicolumn{2}{|c|}{ Study group } & \multicolumn{2}{|c|}{ Control group } \\
\hline & & Medial & Lateral & Medial & Latera \\
\hline \multirow{5}{*}{120} & 1 & 0,0790 & 0,0790 & 0,0790 & 0,0790 \\
\hline & 2 & 0,0800 & 0,0790 & 0,0790 & 0,0810 \\
\hline & 3 & 0,0360 & 0,0490 & 0,0800 & 0,0800 \\
\hline & 4 & 0,0800 & 0,0620 & 0,0450 & 0,0350 \\
\hline & 5 & 0,0490 & 0,0510 & 0,0250 & 0,0390 \\
\hline Average & & 0,0648 & 0,0640 & 0,0616 & 0,0628 \\
\hline $\begin{array}{l}\text { Standard } \\
\text { deviation }\end{array}$ & & 0,0209 & 0,0146 & 0,0253 & 0,0236 \\
\hline $\mathrm{p}$-medial value & & \multicolumn{4}{|c|}{0,690} \\
\hline $\mathrm{p}$ - lateral value & & \multicolumn{4}{|c|}{0,841} \\
\hline
\end{tabular}

Mann-Whitney

TABLE 3 - Measurement of areas in $\mathrm{cm}^{2}$ of healed osteochondral defects in the medial and lateral condyles, the period of 180 days in 05 rabbits of both groups.

\begin{tabular}{|c|c|c|c|c|c|}
\hline \multirow[b]{3}{*}{ Period } & \multirow[b]{3}{*}{ Animal } & \multicolumn{4}{|c|}{ Healed áreas $\left(\mathrm{cm}^{2}\right)$} \\
\hline & & \multicolumn{2}{|c|}{ Study group } & \multicolumn{2}{|c|}{ Control group } \\
\hline & & Medial & Lateral & Medial & Lateral \\
\hline \multirow{5}{*}{180} & 30 & 0.0580 & 0.0670 & 0.0680 & 0.0640 \\
\hline & 32 & 0.0720 & 0.0520 & 0.0450 & 0.0560 \\
\hline & 27 & 0.0620 & 0.0650 & 0.0800 & 0.0530 \\
\hline & 26 & 0.0570 & 0.0380 & 0.0740 & 0.0700 \\
\hline & 23 & 0.0560 & 0.0740 & 0.0670 & 0.0480 \\
\hline Average & & 0.0610 & 0.0592 & 0.0668 & 0.0582 \\
\hline $\begin{array}{l}\text { Standard } \\
\text { deviation }\end{array}$ & & 0.0065 & 0.0143 & 0.0132 & 0.0088 \\
\hline $\mathrm{p}$ - medial value & & \multicolumn{4}{|c|}{0.310} \\
\hline $\mathrm{p}$ - lateral value & & \multicolumn{4}{|c|}{0.841} \\
\hline
\end{tabular}

Mann-Whitney

\section{Discussion}

Biomaterials have been applied in orthopedics for over 60 years and classified into three distinct generations: the first, bio- 
inert material; the second, bioactive and biodegradable materials; and the third, specific stimulators of the cells' response $\mathrm{e}^{3,6,7}$

Second generation materials such as PLA and PGA polymers have been used in vivo to repair osteochondral defects such as support brackets of matrix cells and it was shown that they filled tissue defects with better quality tissue more quickly ${ }^{3,6,7}$.

In this study, BPSCG was used in the repair of osteochondral defects with the aim of completing and providing substrate for the healing of the articular cartilage surface. There is a growing area of tissue formed on the BPSCG with similar dimensions in both the study and control groups.

The measurement of small areas of tissue using a stereomicroscope, photos and the Image $J^{\circledR}$ program was conducted by Pereira et al. ${ }^{10}$ in studies of rat femurs, showing results in quantitative variables, by which the two groups were objectively compared. We used this method being used in our research, because this allows an objective comparison between the healed areas of the osteochondral defects to be made.

Using digital cameras, as part of their photogrammetric methods to measure areas, has been the practice of other authors ${ }^{11}$.

The results found by using BPSCG to fill osteochondral defects showed that the size of the healed area is similar in both groups, which was also evidenced in the qualitative macroscopic features observed by Ribeiro et al. ${ }^{4,5}$ when they used osteochondral grafts to repair the femoral defects condyles of rabbits.

The BPSCG used was low density, a fact that probably did not allow it to be fully incorporated into the osteochondral defects. This line of thinking is due to the results obtained in other papers in which this material was used in dense form, as cited by other authors, for the repair of defects in arterial vessels, membranes, the urinary bladder and hard material ${ }^{11-15}$.

The Mann-Whitney statistical test was used as it is appropriate for the size of our sample and the distribution of data ${ }^{8,9}$.

\section{Conclusion}

The dimension of the healed areas of the defects treated with the biopolymer sugar-cane gel in the study group was similar to those of the control group, which healed naturally.

\section{References}

1. Kim TK, Sharma B, Williams CG, Ruffner MA, Malik A, Mcfarland EG, Elisseeff JH. Experimental model for cartilage tissue engineering to regenerate the zonal organization of articular cartilage. Osteoarthritis Cartilage. 2003;11:653-64.

2. Ossendorf C, Kaps C, Kreuz PC, Burmester GR, Sittinger M,
Erggelet C. Treatment of postraumatic and focal osteoarthritic cartilage defects of the knee with autologous polymer-based threedimensional chondrocyte grafts: two year clinical results. Arthritis Res Ther. 2007;9(2):R41.

3. Navarro M, Michiardi A, Castanõ O, Planell JA. Biomaterials in orthopaedics. J R Soc Interface. 2008;5:1137-58.

4. Ribeiro JL, Camanho GL, Takita LC. Estudo macroscópico e histológico de reparos osteocondrais biologicamente aceitáveis. Acta Ortop Bras. 2004;12:16-21.

5. Amiel D, Coutts RD, Abel M, Stewart W, Harwood F, Akeson WH. Rib perichondrial grafts for the repair of full-thickness articularcartilage defects. A morphological and biochemical study in rabbits. J Bone Joint Surg Am. 1985;67:911-20.

6. Hing KA. Bone repair in the twenty-first century: biology, chemistry or engineering? Philos Transact A Math Phys Eng Sci. 2004;362:2821-50.

7. Spector M. Biomaterials-based tissue engineering and regenerative medicine solutions to musculoskeletal problems. Swiss Med Wkly. 2006;136:293-301.

8. Brittberg M. Autologous chondrocyte implantation - Technique and long-term follow-up. Injury. 2008;39:40-9.

9. Martin-Hernandez C, Cebamanos-Celma J, Molina-Ros A, BallesterJimenez JJ, Ballester-Soleda J. Regenerated cartilage produced by autogenous periosteal grafts: a histologic and mechanical study in rabbits under the influence of continuous passive motion. Arthroscopy. 2010;26:76-83.

10. Pereira AC, Amadei SU, Silveira VA, Balducci I, Faig-Leite H. Estudo comparativo da porcentagem das áreas cortical, trabecular e do canal medular do fêmur de ratos hipertensos(SRH) e normotensos. Ciênc Odontol Bras. 2007;10:64-9.

11. Andrade RR, Kirchner FF. Mensurações com câmeras digitais. Anais XI SBSR, Belo Horizonte, Brasil, 05 - 10 abril 2003, INPE, p.313-5.

12. Beedle MP, Kennedy JF, Melo FAD, Lloyd LL, Medeiros VA. Cellulosic exopolysaccharide produced from sugarcane molasses by a Zooglea sp. Carbohydrate Polymers. 2000;42:375-83.

13. Castro C, Aguiar J, Melo F, Silva W, Marques E, Silva D. Citotoxicidade de biopolímero de cana-de-açúcar. An Fac Med Univ Fed Pernamb. 2004;49:119-23.

14. Lima F, Lima J, Hirakawa P, Medeiros Júnior D, Lima F, Aguiar J. Resposta inflamatória a membranas de biopolímero de cana-deaçúcar e telas de polipropileno re-implantadas no peritôneo parietal de ratos. An Fac Med Univ Fed Pernamb. 2005;50:37-40.

15. Aguiar J, Lins E, Marques S, Coelho A, Rossiter R, Melo R. Sugar cane biopolymer patch in femoral artery angioplasty in dogs. Acta Cir Bras. 2007;22:77-81.

\section{Correspondence:}

Paulo Cezar Vidal Carneiro de Albuquerque

Depto. Cirurgia, UFPE

Av. Prof. Moraes Rego, s/n

50670-901 Recife - PE Brasil

Tel: (55 81)2126-3518

paulovidal_@hotmail.com

Received: January 18, 2011

Review: March 22, 2011

Accepted: April 25, 2011

Conflict of interest: none

Financial source: none

${ }^{1}$ Research performed at Animal Experimentation Unit, Research Center, Department of Surgery, School of Medicine, Federal University of Pernambuco (UFPE), Recife-PE, Brazil. Part of Fellow Master degree. Thesis first author. Tutor: José Lamartine Aguiar, Postgraduate Program Surgery, School of Medicine, UFPE. 